\title{
Compliance with Russia's national development goals and the UN sustainable development goals
}

\author{
Lilia Chaynikova ${ }^{1}$, Natalia Sorokina ${ }^{1,2, *}$, and Daria Melnikova ${ }^{1}$ \\ ${ }^{1}$ Plekhanov Russian University of Economics, 36, Stremyanny per., 117997, Moscow, Russia \\ ${ }^{2}$ Institute of Economics RAS, 32, Nakhimovskiy prospect, 117218, Moscow, Russia
}

\begin{abstract}
The article analyzes the correspondence between the national development goals of the Russian Federation and the UN sustainable development goals in the field of ensuring the quality and accessibility of education. It has been substantiated that the implementation of sustainable development goals in Russia is of great importance for activities to achieve the country's national goals and development priorities. A comparative analysis of the education system in Russia as a source and factor of socioeconomic development and improving the population's quality of life is carried out. An analysis of the comparison between SDG 4 and the national project "Education" led to the following conclusion: the consistency of national policy measures with plans to achieve SDG 4 depends, first of all, on political priorities and national interests of the country and requires intersectoral coordination in planning and monitoring the implementation of targeted activities. Analysis of the compliance of the development goals of Russia within the framework of the implementation of the national projects "Labor productivity and employment support" and "Small and medium-sized entrepreneurship and support of individual entrepreneurial initiative" and SDG 8 showed the importance of institutional and financial instruments, the active use of which in the Russian economy is facilitated by the significant changes in legislation. The problem of mismatch of indicators of the studied documents is determined. For these are no statistical data in the framework of the implementation of sustainable development goals. It is concluded that the national development goals of the Russian Federation in the field of ensuring the quality and accessibility of education are generally consistent with the UN sustainable development goals.
\end{abstract}

\section{Introduction}

Since the $80 \mathrm{~s}$, in the twentieth century, society recognized the global nature of development problems and ensured its sustainable nature was the most important strategic task facing humanity. It was proclaimed that dynamics should be considered sustainable,

\footnotetext{
*Corresponding author: sorokina-tula@mail.ru
} 
meeting the needs of the current generation, without jeopardizing the satisfaction of future generations' needs. This postulate's implementation was taken as the basis for certain at the turn of the XX-XXI centuries. The UN Millennium Development Goals, which included: eliminating poverty and hunger, ensuring universal primary education, promoting gender equality and protecting women's rights, reducing child mortality, improving maternal health, combating HIV, ensuring environmental sustainability, building partnerships for sustainable development [Transforming Our World: The 2030 Agenda for Sustainable Development. Resolution adopted by the UN General Assembly on September 25, 2015 [Electronic resource] - Access mode: https:/documents-ddsny.un.org/doc/UNDOC/GEN/N15/291/92/PDF/N1529192.pdf ? OpenElement]. Thus, humanity was offered a development model that includes four interrelated aspects: economic, social, environmental and institutional [Yu. Bubnov. The history of the concept of sustainable development. Internet project EcoRussia.info. [Electronic resource] - Access mode: http://ecorussia.info/ru/about/part-1-intro.], Reflecting an approach to social dynamics, ensuring rational use of resources, harmonious relationship between man and nature, social stability in society and economic development based on innovation.

In our opinion, the essence of sustainable development can be revealed by analyzing its goals. The presented research approach is shared by many Russian scientists and practitioners [1]. The system of sustainable development goals (SDGs) is regulated by the UN General Assembly document "Transforming Our World: The 2030 Agenda for Sustainable Development", which contains 17 global goals specified in tasks and targets. Without diminishing the importance of each of their established goals, our research focuses on ensuring modern, high-quality education as a source and factor of sustainable development of society and a decent human life.

Foreign researchers [2, 3, etc.] have proved that a low level of education and its low quality create threats to society's sustainable socio-economic dynamics, act as a factor in increasing inequality in the opportunities of the population, especially young people [NEETs. Young people not in employment, education or training: Characteristics, costs and policy responses in Europe.Eurofound.Publications Office of the European Union, Luxembourg, 2012. [Electronic resource] - Access mode: https: //www.eurofound.europa.eu/sites/default/files/ef_publication/field_ef_document/ef1254en. pdf], in the field of human capital formation and development. This postulate was also confirmed in the studies of Russian scientists: EV Romanov [4] argued that Russia's ability to create effective mechanisms to counter the "brain drain" at the state level is a significant factor determining the potential for overcoming crisis trends in the economy and the country's entry into the sixth technological order; NOT. Serditova and AV Belotserkovsky [5] proved that the unprecedented speed and scale of social changes turn education, above all, higher education, into a guarantor of the country's successful adaptation to technological changes in the context of global digital transformation.

The leading role of education in achieving the goals of Russia's sustainable socioeconomic development is also recognized at the state level. Within the framework of the national goal, "Opportunities for self-realization and development of talents", a target priority was determined - the country's entry into the top ten countries in the world in terms of the quality of general education [Decree of the President of the Russian Federation of July 21, 2020 No. 474 "On the national development goals of the Russian Federation for the period up to 2030 ". [Electronic resource] - Access mode: https://www.garant.ru/products/ipo/prime/doc/74304210/]. Thus, ensuring the accessibility and quality of education is one of the priority tasks for the Russian Federation's development. 
Recognizing the key role of education in creating conditions for sustainable development of countries and dignified life for the population, the UN has formulated SDG 4 and SDG 8, linking levels of education, employment, and economic growth (Fig. 1).

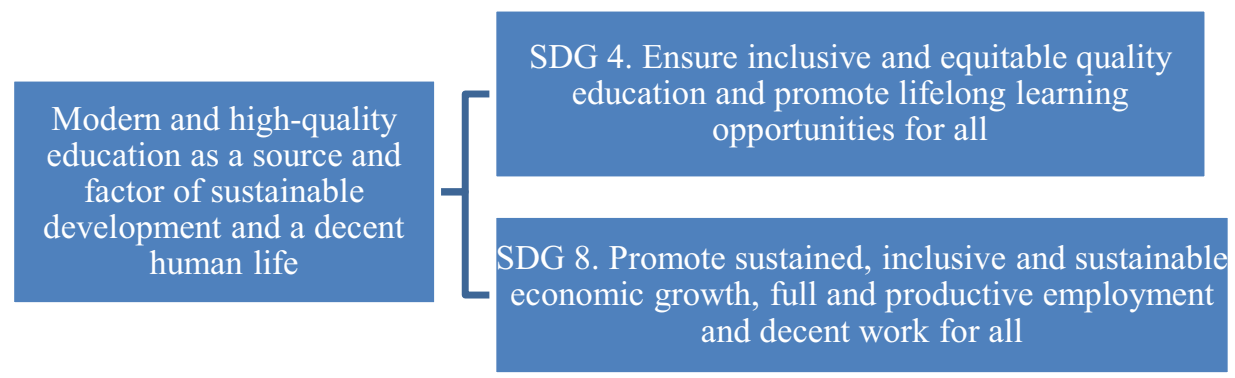

Fig. 1. Relationship between the categories "education", "employment" and "socio-economic development" in the UN SDGs.

\section{Materials and methods}

\subsection{Data}

The national project (NP)"Education" is dedicated to addressing issues of ensuring the quality and accessibility of services in the education system, as well as several program documents, in particular, the state program "Development of Education", which contains a set of measures aimed at facilitating the expansion of participation of the population in additional education programs. SDG 8 targets are being addressed within the national projects "Labor productivity and employment support" and "Small and medium-sized enterprises and support for individual entrepreneurship". These strategic documents were used as the main source of data since they allow for a comprehensive analysis and discussion of the degree to which the Russian Federation and the UN SDGs' national development goals are consistent. Official statistics (Rosstat) and the portal "National Projects of Russia" were also used as an informational basis for the study (Table 1):

Table 1. Comparison of the UN sustainable development goals and national projects of Russia.

\begin{tabular}{|c|c|}
\hline SDG context & National project in Russia context \\
\hline $\begin{array}{l}\text { SDG } 4 \text { [Sustainable } \\
\text { Development Goals in the } \\
\text { Russian Federation. 2020: } \\
\text { Brief statistics / Rosstat, 79 } \\
(2020)]\end{array}$ & 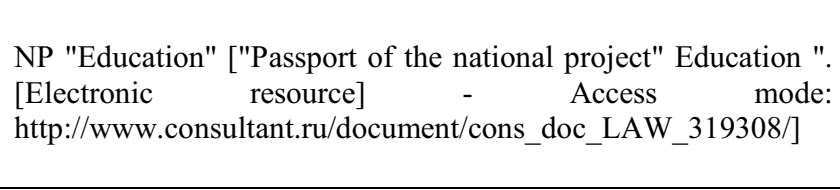 \\
\hline $\begin{array}{l}\text {-Provide of inclusive and } \\
\text { equitable quality education; } \\
\text { - Promote lifelong learning } \\
\text { opportunities for all }\end{array}$ & $\begin{array}{l}\text { - ensuring the global competitiveness of Russian education; } \\
\text { - education of a harmoniously developed and socially } \\
\text { responsible personality based on national-historical, cultural } \\
\text { traditions and spiritual and moral values }\end{array}$ \\
\hline $\begin{array}{l}\text { SDG } 8 \text { [Sustainable } \\
\text { Development Goals in the } \\
\text { Russian Federation. 2020: } \\
\text { Brief statistics / Rosstat, 79 } \\
(2020) \text { ] }\end{array}$ & $\begin{array}{l}\text { NP "Labor Productivity and Employment Support" } 2024 \\
\text { [Sustainable Development Goals in the Russian Federation. } \\
\text { 2020: Brief statistics / Rosstat, } 79(2020) \text { ] }\end{array}$ \\
\hline $\begin{array}{l}\text { Promote sustained, inclusive } \\
\text { and sustainable economic }\end{array}$ & $\begin{array}{l}\text { - Dissemination of knowledge in the field of increasing labor } \\
\text { productivity }\end{array}$ \\
\hline
\end{tabular}




\begin{tabular}{|l|l|}
\hline $\begin{array}{l}\text { growth, full and productive } \\
\text { employment and decent } \\
\text { work for all }\end{array}$ & $\begin{array}{l}- \text { Stimulating interest in increasing labor productivity from } \\
\text { enterprises, regional and federal authorities }\end{array}$ \\
\cline { 2 - 2 } & $\begin{array}{l}\text { NP "Small and Medium Business" [National Project: Small and } \\
\text { Medium Business. [Electronic resource] - Access mode: } \\
\text { https://xn--80aapampemcchfmo7a3c9ehj.xn--p1ai/projects/msp] }\end{array}$ \\
\cline { 2 - 2 } & $\begin{array}{l}\text { support the business at all stages of its development: from the } \\
\text { initial idea to expansion and export. Administrative barriers are } \\
\text { removed, the very image of an entrepreneur is promoted. }\end{array}$ \\
\hline
\end{tabular}

\subsection{Research approach}

The study is based on the comparative analysis methodology's key provisions, which makes it possible to study the problems of socio-economic development of complex systems in time and space. As a key method used for analysis and comparison, content analysis was applied, a method of collecting data and analyzing text, involving obtaining conclusions and conclusions based on studying the content of publications of authoritative researchers of a specific scientific and practical problem. The method allows to obtain reproducible, accurate results based on the study of publicly available texts using semantic analysis, presenting the results in the form of graphs, diagrams, diagrams and tables.

\section{Results}

SDG 4 targets are global and require integration and transformation into national public policies to develop education. SDG 4 indicators include 11 global indicators and 7 national ones defined for Russia.

The current demand to increase the chances of all children, including those from disadvantaged families and children with disabilities, to socialize aims to achieve equality in access to preschool education to prepare for school. It is based on this requirement that one of the objectives of SDG 4 was formulated "To provide all girls and boys with access to quality systems for the development, care and preschool education of young children", correlated with two objectives of the national project "Education": "Creating conditions for the early development of children in under 3 years of age "and" Creation of a modern and safe educational environment".

In recent years, the coverage of children under 3 years of age with preschool education has changed very slightly and amounted to about $20 \%$ of the number of children in the corresponding age group. The current situation was formed under the influence of two factors: a significant increase in the number of young children due to the implementation of the state policy to support the birth rate in the country and the limited number of places in the preschool education system. This contradiction, in our opinion, will persist in the foreseeable future and may become a source of risk of failure to achieve the target indicators of SDG 4. As a positive trend, a $7.4 \%$ increase in the share of preschool educational institutions with a universal barrier-free environment, creating comfortable conditions for inclusive education, should be noted children with disabilities, which was achieved thanks to the State's active implementation Program "Accessible Environment".

SDG target 4, which provides guarantees of all girls and boys' opportunity to receive free, equal and high-quality primary and secondary education, is also reflected in the corresponding indicators of Russian educational practice. The increase in the availability of educational services for persons with disabilities, an increase in the level of its practical orientation is evidenced by the positive dynamics of the indicator of the share of graduates with disabilities in grades 9 and 11, covered by vocational guidance, in the total number of graduates with disabilities, over the past five years has grown from 80 to $95 \%$. 
The Russian education system structure fully allows the implementation of SDG 4, aimed at encouraging lifelong learning opportunities and for all groups and categories of the population. Within the framework of our research, the most interesting is the analysis of the possibilities of professional and higher education in providing conditions for the implementation of "education throughout life" programs. In our opinion, negative trends in the dynamics of secondary vocational education in Russia are a significant source of risk of failure to achieve SDG 4 targets: the gross enrollment ratio in educational programs (as a percentage of the population aged 15-19) has been steadily decreasing from $16.6 \%$ in 2014. . to $12.7 \%$ in 2018 , which indicates a low demand for programs of this level of education among young people due to the possible low prestige of future professions [6]. On the other hand, according to forecasts of BusinesStat analysts in 2022-2024. the growth of the market of secondary vocational education in Russia should be expected by $1.4 \%$ annually, and by 2024 its volume may reach 3.89 billion acad. hours, which will exceed the level of 2019 by $3.7 \%$ [Analysis of the market of secondary vocational education in Russia in 2015-2019, assessing the impact of coronavirus and forecast for 2020-2024. [Electronic resource] Access mode: https://marketing.rbc.ru/research/27924/]. In general, the task of the national project "Education" related to the "modernization of vocational education through the introduction of adaptive, practice-oriented educational programs", in terms of the development of vocational education, can be solved in the process of developing the interaction of educational institutions with partner enterprises, which will contribute to the identification of priority professions in demand for the development of training programs aimed at the rapid adaptation of graduates to the labor market.

In Russia, the main mechanism for ensuring the availability of higher education and training specialists focusing on the needs of the national economy is the mechanism for forming an order for training at the expense of the federal budget. Currently, the target is the norm of at least 800 students per 10 thousand people between 17 and 30, living in the Russian Federation. In fact, in 2018-2019 academic year. The number of students in secondary vocational education programs amounted to 3006.4 thousand people. or 168 students per 10,000 population; students of higher education programs - 4161.7 thousand people. or 284 students per 10,000 population [Voluntary National Review of the Implementation of the 2030 Agenda for Sustainable Development. [Electronic resource] Access mode: https://roscongress.org/upload/medialibrary/572/26421VNR_2020_Russia_Report_Russian .pdf]. The data indicate that the potential for developing the domestic system of vocational and higher education has not yet been fully realized.

The development of the Russian system of continuing education is interconnected with the SDG 4 sub-task "To ensure by 2030 for all women and men equal access to affordable and high-quality vocational and technical and higher education, including university education", the implementation of which is monitored using the global indicator " coefficient of participation of youth and adults in formal and non-formal education and training over the past 12 months "[Draft document" Key directions of development of Russian education to achieve the Goals and objectives of sustainable development in the education system "until 2035 [Electronic resource] - Access mode: http : //edu2035.fironir.ru/index.php/stati-opublikovannye-uchastnikami-soobshchestva/86-klyuchevye-

napravleniya-2035\#_Toc32484581] Statistical materials for this indicator are currently available only for the countries of the European Union. In Russia, as in many other indicators, the methodology and tools for conducting statistical surveys and reporting are being developed, including in the context of the constituent entities of the Federation.

The main factor in ensuring sustainable economic growth is an increase in labor productivity, which is reflected in SDG 8 , the tasks of which are solved within the 
framework of the national projects "Labor productivity and employment support" and "Small and medium-sized enterprises and support of individual entrepreneurial initiative".

When comparing the indicators characterizing the SDGs and national projects, it is necessary to pay attention to the indicator that is absent among the main indicators and indicators of national projects: the proportion of young people (aged 15 to 24) who do not study, do not work and do not acquire professional skills. This indicator, of course, has a direct impact on labor productivity by increasing youth employment, ensuring their expanded access to secondary, vocational and higher education. Researchers note personnel training as one of the factors of productivity changes [7], the transition to an intensive model of economic growth.

The report 'Global Trends in Youth Employment 2020: Technology and Tomorrow's Jobs' shows that, since 2017, there has been a trend towards an increase in the number of young people who are not working, not studying or acquiring skills. In 2016, there were 259 million such young people, in 2019 their number was already estimated at 267 million, and in 2021 it is projected to grow to 273 million. A similar trend is observed in percentage terms: in $2015-21.7 \%$, in $2020-22.4 \%$. Statistics show that the international community's goal - to significantly reduce by 2020 the proportion of young people who are not working, not studying or acquiring professional skills - will remain unfulfilled [Global Employment Trends for Youth 2020: Technology and the future of jobs. Opening mode: https://www.ilo.org/global/publications/books/WCMS_737648/lang--en/index.htm].

It is generally recognized that the fight against youth unemployment, which generates a high level of social insecurity and a sense of their uselessness, could significantly contribute to the development of the world economy. According to the ILO, "reducing the youth unemployment rate by $1 \%$ would double the global GDP growth" [8], since those who successfully start working life have a lower risk of long-term unemployment in the foreseeable future [9].

As a positive trend, it should be noted that there are fewer young people in Russia who do not study, do not work and do not acquire professional skills [Young people in Russia began to study and work more / [Electronic resource] - Access mode: https://news.rambler.ru/community/43013326-molodezh-v-rossii-stala-bolshe-uchitsya-irabotat/amp/] . Table 2 shows the dynamics of changes in the indicator, taking into account the distribution of people by sex and settlement type.

Table 2. Dynamics of the young people aged 15 to 24 who do not study, work or acquire skills in Russia.

\begin{tabular}{|c|c|c|c|c|c|c|c|c|c|c|}
\hline & \multicolumn{2}{|c|}{2013} & \multicolumn{2}{|c|}{2014} & \multicolumn{2}{|c|}{2015} & \multicolumn{2}{|c|}{2016} & \multicolumn{2}{|c|}{2017} \\
\hline & $\stackrel{*}{*}$ & 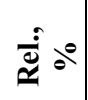 & 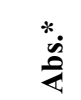 & $\stackrel{\dot{\vec{\Phi}}}{\simeq} \partial^{\circ}$ & 苍 & 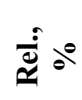 & $\begin{array}{l}* \\
\stackrel{0}{0}\end{array}$ & 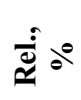 & $\stackrel{*}{*}$ & 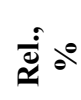 \\
\hline & \multicolumn{10}{|c|}{ Gender distribution } \\
\hline Total & 2273 & 11.8 & 2165 & 12.0 & 2067 & 12.0 & 2000 & 12.4 & 1959 & 12.9 \\
\hline Men & 911 & 9.3 & 872 & 9.5 & 846 & 9.6 & 851 & 10.3 & 860 & 11.1 \\
\hline Women & 1363 & 14.4 & 1294 & 14.7 & 1221 & 14.5 & 1150 & 14.6 & 1099 & 14.8 \\
\hline & \multicolumn{10}{|c|}{ Distribution by settlement type } \\
\hline Total & 2273 & 11.8 & 2165 & 12.0 & 2067 & 12.0 & 2000 & 12.4 & 1959 & 12.9 \\
\hline Tow & 1465 & 10.1 & 1348 & 10.4 & 1348 & 10.4 & 1281 & 10.6 & 1256 & 11.1 \\
\hline Village & 808 & 17.0 & 757 & 17.1 & 719 & 17.0 & 719 & 17.9 & 703 & 18.1 \\
\hline
\end{tabular}

* - absolute values are presented in thousand peoples.

According to the above statistics, the number of young people aged 15 to 24 who do not study does not work and does not acquire skills, both in absolute and relative terms, in 2013-2017. decreases. At the same time, this indicator is higher among women than among 
men, and in rural areas, it is higher than in cities. In 2018, the share of young people (aged 15 to 24 ) who do not study, work and acquire professional skills was $10.17 \%$. In 2019, this figure rose to $10.6 \%$. Experts explain the growth of the indicator that young people are leaving the cult of consumption and traditional types of earnings [Generation Z: there are more young people in the Russian Federation who do not study and do not work. [Electronic resource] - Access mode: https://news.ru/society/molodezh-rabota-ucheba/].

In general, it can be concluded that Russia has achieved noticeable results in providing employment and employment for young people, including implementing a national project.

To address SDG target 8 - "Promote development-oriented policies that promote productive activities, decent jobs, entrepreneurship, creativity and innovation, and encourage the formalization and development of micro, small and medium-sized enterprises, including through the provision of access to financial services "- the national project" Small and Medium Enterprises and Support for Individual Entrepreneurial Initiatives "is focused, which envisages an increase in Russia by 2024 in the number of people employed in small and medium-sized businesses, including individual entrepreneurs (SMEs), to 25 million people As of March 10, 2020, there are 5.96 million SMEs in Russia with more than 15 million employees. The share of SMEs in Russia's GDP in 2018 was $20.2 \%$, and in the volume of non-primary exports - 9.8\% [Voluntary National Review of the Implementation of the 2030 Agenda for Sustainable Development. [Electronic resource] - Access mode: https://roscongress.org/upload/medialibrary/572/26421VNR_2020_Russia_Report_Russian .pdf].

The development of SMEs in the Russian Federation is facilitated by the significant changes in legislation adopted in 2017-2019, which have a positive impact on the activities of SMEs, including: expanding access to procurement; expanding the criteria for referring to SMEs; credit and guarantee support, deposit insurance; improving the effectiveness of control and supervision; provision of tax benefits, simplification of reporting; concessional leasing support [Voluntary National Review of the Implementation of the 2030 Agenda for Sustainable Development. [Electronic resource] - Access mode: https://roscongress.org/upload/medialibrary/572/26421VNR_2020_Russia_Report_Russian .pdf]. Currently, Russia continues to create the necessary conditions for the development of small and medium-sized businesses, which, under certain conditions, can become a key driver for the development of certain sectors of the economy of the future [10].

\section{Discussion}

The problem of establishing the correspondence between national development goals, priority for the Russian Federation, and the UN sustainable development goals is being actively studied by Russian scientists and specialists in the field of state and municipal administration. Our conclusions and conclusions are generally consonant with the results obtained by authoritative Russian researchers and international research teams. In particular, the main postulate - the national development goals of the Russian Federation in education development are generally consistent with the UN sustainable development goals - is confirmed by NM's research. Milovantseva, A. Earl and D. Heyman [1], who, however, emphasize the need to develop a particular state policy to bring Russia closer to the implementation of the UN SDGs. Authors of the "Report on Human Development in the Russian Federation. The UN Sustainable Development Goals and Russia "[Human Development Report in the Russian Federation for 2018 / [Electronic resource] - Access mode: https://ac.gov.ru/archive/files/publication/a/19663.pdf], who has made a rather successful attempt to adapt the main priorities of the SDGs to Russian realities and prospects, emphasize that the SDGs can become targets, the foundation of a national 
discussion about the country's future. Simultaneously, the researchers substantiate the need to expand the discussion on the problems of sustainable development of the country in all their diversity.

In our opinion, a promising direction for the development of scientific and practical research is the question of the extent to which the strategic development goals of the Russian Federation, relevant to the UN SDGs, are integrated and with the priority areas of the state's socio-economic policy.

\section{Conclusion}

The national development goals of the Russian Federation in the field of education are generally coordinated with the UN sustainable development goals. In our opinion, ensuring modern and high-quality education as a source and factor of sustainable development and a decent human life should be recognized as a priority over economic problems.

The analysis of the comparison of the SDGs "Ensuring inclusive and equitable quality education and the promotion of lifelong learning opportunities for all" and the goals of the National Project "Education" led to the following main conclusions:

- special attention, in our opinion, deserves the SDG indicator "Proportion of adults and young people with skills in the field of information and communication technologies", since the national project as one of the priority tasks provides for the possibility of mastering basic general educational programs, including in the network form, as well as obtaining additional education for adults online. At the same time, it was found that Russia lags behind the developed European countries in this indicator, which negatively affects the quality and speed of receiving educational services;

- the coverage of children under 3 years of age with preschool education remains low (22.2\% in 2018), which is explained by the insufficient network of preschool educational institutions. The stable positive dynamics of an increase in the share of preschool educational institutions with the universal barrier-free environment has been created for the inclusive education of children with disabilities. This indicates the implementation of one of the priorities of the Russian educational policy in providing opportunities for preschool education for children with various developmental and health disabilities.

Analysis of the correspondence between the development goals of Russia within the framework of the implementation of the national projects "Labor productivity and employment support" and "Small and medium-sized enterprises and support of individual entrepreneurial initiative" and the SDGs "Promotion of progressive, inclusive and sustainable economic growth, full and productive employment and decent work for all ", Showed:

- the composition of the indicators of these documents differs in many respects, while, in our opinion, special attention should be paid to the indicator of the number of young people who do not work, do not study and do not acquire professional skills, which is absent among the indicators characterizing national projects in Russia. The growth of this indicator, of course, negatively affects the socio-economic development of Russia as a whole and, in particular, contributes to a decrease in labor productivity, which in turn weakens the competitiveness of the Russian economy in the international market;

- the main instruments for supporting small and medium-sized businesses in SDG 8 and the national project "Small and Medium-Sized Businesses and Support for Individual Entrepreneurial Initiatives" are financial instruments, the active use of which in the Russian economy is facilitated by the significant changes in legislation adopted in 2017-2019.

Thus, the system of UN sustainable development goals can be proposed as a basic goalsetting system, within the framework of which the main priority directions of the strategic development of the Russian Federation, promising targets for the dynamics of industries 
and territories are determined and concretized, the foundations of state policy in the field of sustainable development of the state are formed.

\section{References}

1. N. Milovantseva, A. Yorl, D. Kheyman, Vestnik mezhdunarodnykh organizatsiy 13(4), 122-143 (2018) DOI: 10.17323/1996-7845-2018-04-06

2. A. Wojciuk, M. Michałek, M. Stormowsk, European Political Science 14(3), 298-317 (2015) DOI: 10.1057/eps.2015.25

3. J. Stetar, S. Coppla., L. Guo, N. Nabiyeva, B. Ismailov, Soft power strate-gies: competition and cooperation in a globalized system of higher, 191-203 (2010) DOI: 10.1057/9780230106130_14

4. Ye. Romanov, Obrazovaniye i nauka 22(9), 107-147(2020) DOI: 10.17853/19945639-2020-9-107-147

5. N. Serditova, A. Belotserkovskiy, Vyssheye obrazovaniye v Rossii 4, 9-15 (2020) DOI: 10.31992/0869-3617-2020-29-4-9-15

6. D. Danilayev, N. Malivanov, Vyssheye obrazovaniye v Rossii 30(1), 60-72 (2021) DOI: 10.31992/0869-3617-2021-30-1-60-72

7. I. Korshunov, O. Gaponova, N. Gaponova, Ekonomika regiona 15(1), 107-120 (2019) DOI 10.17059/2019-1-9

8. V. Bobkov, A. Litvinyuk, S. Ledneva, Ekonomika regiona 12(4), 1102-1112 (2016) DOI 10.17059/2016-4-12

9. V. Koksharov, G. Agarkov, A. Sushchenko, Ekonomika regiona 15(2), 337-349 (2019) DOI 10.17059/2019-2-3

10. N. Solodilova, R. Malikov, K. Grishin, Ekonomika regiona 13(4), 1107-1122 (2017) DOI 10.17059/2017-4-11 